Article

\title{
Avian Reporting Rates in Chugcheongnam Province, South Korea Depend on Distance from Forest Edge, Size of Trees, and Size of Forest Fragments
}

\author{
Woongsoon Jang ${ }^{1}$, Ara Seol ${ }^{2}$, Ok-Sik Chung ${ }^{3}$, Junghee Sagong ${ }^{3}$ and Jong Koo Lee ${ }^{4, *}$ \\ 1 Department of Forest Resources Management, The University of British Columbia, 2424 Main Mall, \\ Vancouver, BC V6T 1Z4, Canada; woongsoon.jang@gmail.com \\ 2 Division of Forest Industry, National Institute of Forest Science, 57 Hoegi-ro, Dongdaemun-gu, Seoul 02455, \\ South Korea; araseol@korea.kr \\ 3 Space and Environment Laboratory, Chungnam Institute, 73-26 Institute Road, Gongju, South Chungcheong \\ Province 32589, South Korea; nansamata@hanmail.net (O.-S.C.); sun-road@cni.re.kr (J.S.) \\ 4 Division of Life Science, Incheon National University, 119 Academy-ro, Yeonsu-gu, \\ Incheon 22012, South Korea \\ * Correspondence: jklee@inu.ac.kr; Tel.: +82-32-835-8895
}

Received: 18 March 2019; Accepted: 26 April 2019; Published: 26 April 2019

check for updates

\begin{abstract}
Forests provide bird communities with various resources, including food and habitats. Thus, forest attributes, such as size, structure, and species composition, influence the distribution and dynamics of bird species. This study was conducted to examine the association between forest condition, bird species abundance, and diversity within Chungcheongnam Province, South Korea. Zero-inflated binomial regression models were used to analyze a total of 1646 sampling points of abundance and diversity. Forest area, distance to forest edge, and tree size class were selected as covariates. Negative associations between forest area and overall bird abundance and species richness were indicated, whereas distance to forest edge was not a significant factor. This insignificance may be attributed to the relatively small, fragmented, and homogenous forest areas across the studied region. Results for individual bird species indicated that six out of the 35 major bird species had significant associations to the forest edge and three species showed a preference for the interior of the forest. The results of this study imply that other factors, such as food availability and biotic interaction, are more important when determining habitat preference in a relatively homogenous area with a long history of human disturbance.
\end{abstract}

Keywords: bird species diversity; forest management; wildlife management; fragmentation; habitat preference

\section{Introduction}

Since the 1960s, South Korea has become one of the most urbanized countries in the world [1,2]. During this period of rapid development, many forested habitats were lost or fragmented [3]. Because the changes in land cover and land-use patterns affect the various ecosystem functions substantially [4], habitat loss and fragmentation are known to be the primary driving forces behind the global biodiversity crisis [5-8]. The question regarding the ecological effects of fragmented forests has yielded a series of research studies to determine the relationship between forest fragmentation and fauna and flora [9], not only in South Korea (e.g., $[10,11])$ but also around neighboring countries such as Japan and China (e.g., [12-15]). However, there are still knowledge gaps, especially at larger spatial scales such as landscape or regional levels [4,16]. 
Forests within landscapes have spatial configurations based on their structural and compositional conditions [17]. Structural and compositional attributes are often characterized by various properties such as tree size and cover [18], understory vegetation [19], abundance and distribution of snags [20], and topography $[19,21]$. The complexity and spatial pattern of these attributes can alter microclimates and the amounts of available resources [22,23], resulting in an array of micro and macro habitats, influencing the distribution and dynamics of wildlife populations [5,24-26].

As an example of spatial configuration influence on wildlife species distribution, it is generally assumed that forest area and bird species diversity have a positive relationship [27]. Such relationships have been found in Japan [27,28] and South Korea [29]. Natuhara and Imai [27] reported a positive relationship between forest bird richness in urban woods in Osaka Prefecture, Japan. Yamaura et al. [28] also reported a positive relationship between plantation area and bird species richness in central Japan. In South Korea, Park and Lee [29] similarly found a positive relationship in urban forests in Seoul, however, the responses of birds to spatial configuration of the habitat may be species-specific. Ornithologists categorize specialized species of forest birds into two broad categories according to their habitat preference: edge and forest-interior species [25,30-32]. In Japan, Kurosawa and Askins [33] suggested that forest interior species have a positive relationship with forest area whereas forest edge species are negatively related with forest area. In South Korea, similar classifications are anecdotal and have not previously been examined quantitatively.

Understanding species habitat preference is important for several management and conservation reasons. First, effective conservation plans for specialized species necessitate quantitative evaluation of the species [34]. Thereby, knowledge can be used as an important tool for species diversity management [35]. Moreover, responses of bird communities often play a role in gauging the impacts of natural or anthropological disturbance as well as the efficacy of forest management and restoration efforts $[36,37]$. At a landscape or a regional level, this information can be used to determine priority areas [38] and to maintain and build habitat networks [39].

The Biotope Mapping project in South Korea's Chungcheongnam Province provides a unique opportunity to address these topics. Between 2008 and 2014, every biotope throughout the province was classified, identified, and mapped. As a part of the project, intensive and extensive data sampling was conducted for wildlife (including bird species, with over 2000 sampling points) simultaneously. Capitalizing on the abundance of sampling data, we can establish effective and feasible forest management plans that account for the responses of bird species within the target area/region.

The study objective was to investigate the relationship between the avian community and forest condition. In particular, forest area, tree size, and distance from the forest edge were examined in relation to overall species diversity and abundance. We hypothesized that (1) forest area, deciduous forest, larger tree size class, and longer distance from the forest edge have positive associations with overall species diversity and abundance, and (2) each species has discernable preferences for those forest condition factors.

\section{Methods}

\subsection{Study Sites}

The study was conducted in the Province of Chungcheongnam, located in the western part of South Korea $\left(35^{\circ} 00^{\prime} \sim 37^{\circ} 06^{\prime} \mathrm{N}, 126^{\circ} 13^{\prime} \sim 127^{\circ} 63^{\prime} \mathrm{E}\right)$. The total area of the province is $8226 \mathrm{~km}^{2}$. Approximately $50 \%\left(4080 \mathrm{~km}^{2}\right)$ of the total land area consists of young forests ( $~ 80 \%$ of forests have been reforested during the last four decades), with the average stocking volume of $139 \mathrm{~m}^{3} /$ ha [40]. Coniferous, deciduous, and mixed forests occupied $37 \%, 30 \%$, and $27 \%$ of the total forest area, respectively. The remaining land areas ( $31 \%$ of total area) are primarily used for agriculture, including rice paddies and vegetable fields [41].

The climate of Chungcheongnam is characterized as continental with cold winters and hot and humid summers [42]. The 30-year average temperature of Chungcheongnam is approximately $13^{\circ} \mathrm{C}$, 
with the minimum and maximum monthly average temperatures being $0{ }^{\circ} \mathrm{C}$ (January) and $27^{\circ} \mathrm{C}$ (July), respectively [40]. The average annual precipitation measured from 1981 to 2010 was approximately $1310 \mathrm{~mm}$. This precipitation was mostly concentrated in the summer (July to September) [43].

\subsection{Data Collection and Analyses}

Field sampling was conducted by point counts between 2005 to 2011. To investigate assemblage composition, sampling sites across Chungcheongnam Province were randomly selected using ArcGIS 10.1 (ESRI, Redlands, CA, USA) (Figure 1). A total of 2024 sampling points were assigned with sufficient buffers to avoid counting duplications. Line transects were deployed [44], which involved walking in a straight line in a random direction for 20 minutes. During this time, the number and species of birds were observed in each sampling transect. Data were collected by audiovisual methods (with binoculars and identifying bird calls) through the morning. Three skilled observers conducted the survey consistently throughout all field samplings. Since this study focused on forested areas, sampling points (i.e., starting points of the transects) located outside of these areas were excluded.

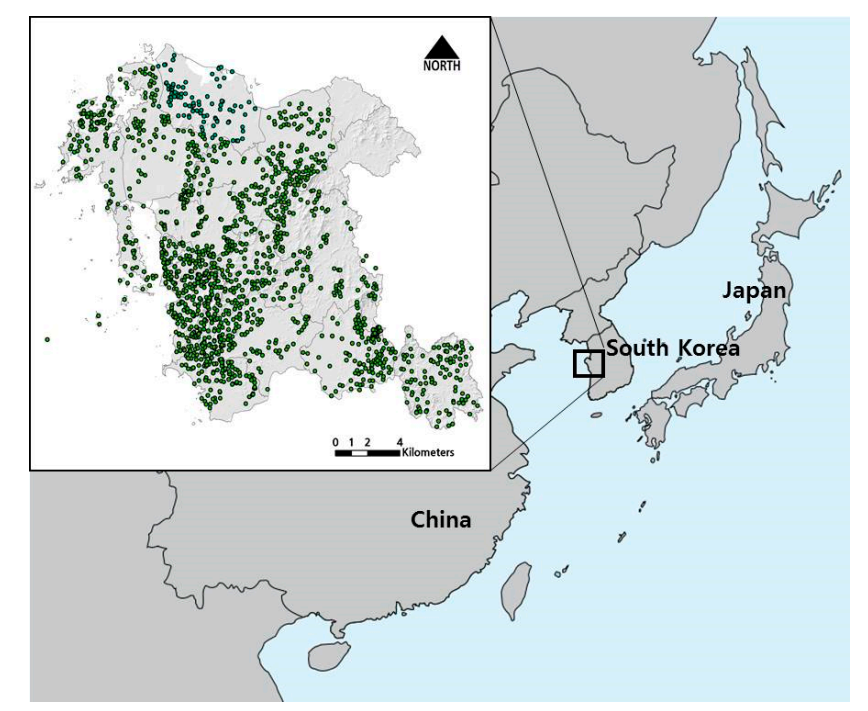

Figure 1. Sampling sites in Chungcheongnam Province.

Using ArcGIS 10.1 (ESRI, Redlands, CA, USA), forest information within the sampling sites was extracted from the Korea Forest Cover Type Map at a scale of 1:5000 (Korea Forest Service, Daejeon, South Korea). Data for forest area, distance to nearest forest edge, and tree size classes were extracted for each sampling point (Table 1). This study utilized the Korea Forest Cover Type Map's tree size classification and forest types. The size classes were classified with the median diameter at breast height (DBH) of trees in the stand: (a) $<6 \mathrm{~cm}$, size class 0; (b) 6-18 cm, size class 1; (c) 18-30 cm, size class 2; and (d) $>30 \mathrm{~cm}$, size class 3 . The forest types were classified into coniferous, deciduous, and mixed forests. Other minor forests types (e.g., bamboo forest) were excluded due to no sampling data (Table 1). These variables were used as explanatory variables throughout the analyses. 
Table 1. Description of forest condition variables.

\begin{tabular}{cccccc}
\hline Variables (Units) & Notation & Min. & Max. & Mean & Note \\
\hline $\begin{array}{c}\text { Forest area }\left(\mathrm{m}^{2}\right) \\
\text { Forest type (proportion: \%) }\end{array}$ & Area & 229 & $1,412,772$ & 52,085 & $\begin{array}{c}\text { Log-transformed } \\
\text { Categorical variable } \\
\text { Coniferous }\end{array}$ \\
$\begin{array}{c}\text { Deciduous } \\
\text { Mixed-species }\end{array}$ & F_type1 & & & 37 & Reference level \\
Others & F_type3 & & & 30 & \\
F_type4 & & & 27 & Not sampled \\
Distance to forest edge (m) & Dist & 0 & 88 & 14.5 & \\
Tree size class (No. sites) & & & & Categorical variable \\
0 & SizeCL0 & & & 63 & $<6$ cm \\
1 & SizeCL1 & & 412 & $6-18 \mathrm{~cm}$ \\
2 & SizeCL2 & & 1154 & $18-30 \mathrm{~cm}$; reference level \\
3 & SizeCL3 & & 17 & $>30 \mathrm{~cm}$ \\
\hline
\end{tabular}

Overall species richness (number of bird species) and abundance (number of individual birds) were used to evaluate the effect of forest conditions on bird communities. Species richness and abundance were analyzed through a generalized linear modeling approach. Negative binomial distribution was introduced to incorporate count data and overdispersion.

For analysis at the individual species level, bird species detected at fewer than 50 plots were excluded from individual species analyses, which consequently involved 35 species. Zero-inflated negative binomial regression was employed to model bird count data and handle the excessive zero observations $[45,46]$. A standard negative binomial generalized model was used if the zero-inflation model failed to find the optimum solution. Log-transformed distance to forest edge, log-transformed forest area, and tree size classes were tested as covariates for parameter estimation for both community and species level analyses (i.e., count and zero-inflation processes). This study used the GENMOD procedure of SAS statistical software 9.4 (SAS Institute Inc. Cary, NC, USA) to fit the models.

\section{Results}

This survey recorded a total of 140 bird species. A total of 1646 sampling sites were used for analysis. On average, 7.0 species and 18.7 individuals were recorded per plot. There was a negative association between bird species abundance and log-transformed forest areas (Figure 2). Tree size class 3 had higher bird counts than forests with the tree size class 2 (Table 2). Bird species richness was also negatively associated with forest area. However, the tree size class 3 and coniferous stands were not statistically significant ( $p=0.0649$ and 0.0774 , respectively). There was insufficient evidence to determine the effect of distance to forest edge for overall species richness and abundance $(p=0.4199$ and 0.7685 , respectively; Table 2 ). 

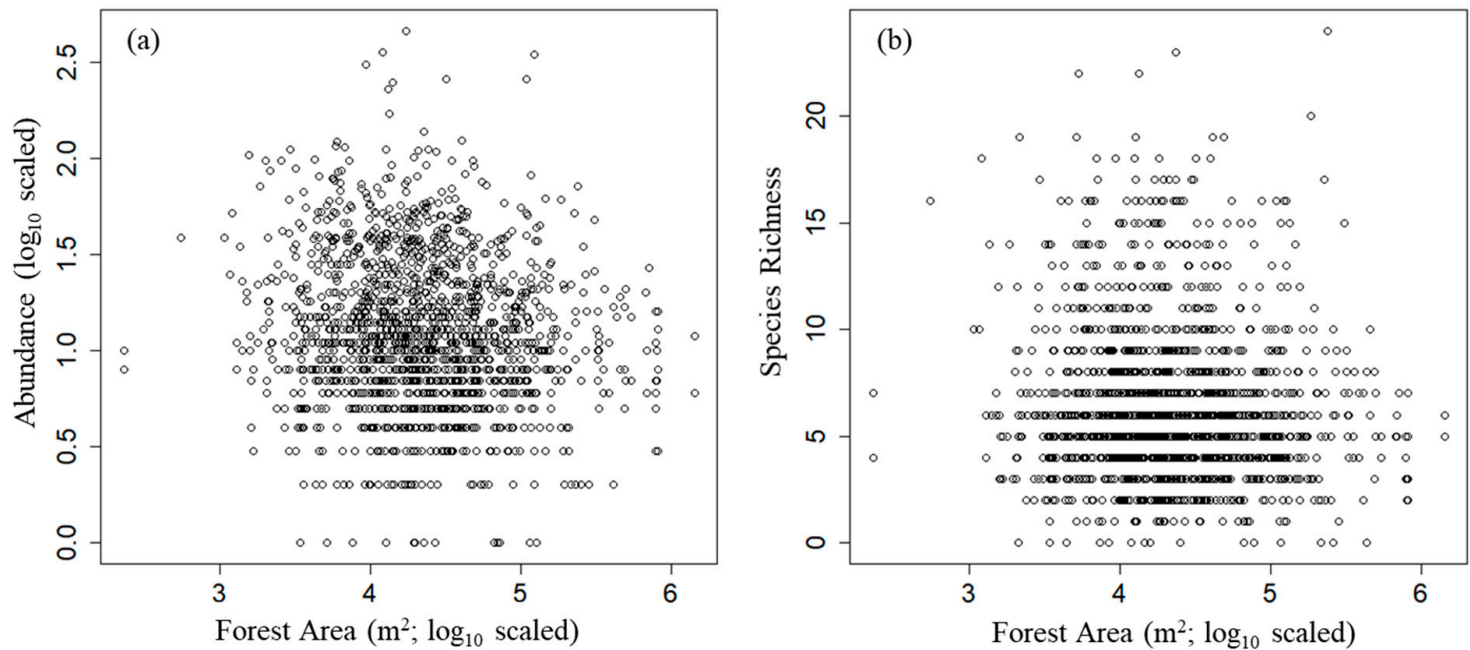

Figure 2. Relationships between forest area and (a) abundance and (b) species richness. Note that the $x$-axes for both figures and $y$-axis for abundance were depicted through logarithmic scales for readability (base: 10).

Table 2. Test result (negative binomial regression model) summary for overall species abundance and richness. Notation: df: degrees of freedom; SE: standard error; Ln: natural logarithm; Area: forest area; Dist: distance to forest edge; F_type: forest type; SizeCL: tree size class (for further details, refer to Table 1 and the main text).

\begin{tabular}{cccccccc}
\hline \multirow{2}{*}{ Variables } & \multirow{2}{*}{ df } & \multicolumn{3}{c}{ Abundance } & \multicolumn{3}{c}{ Richness } \\
\cline { 3 - 7 } & & Estimate & SE & $\boldsymbol{p}$-Value & Estimate & SE & $\boldsymbol{p}$-Value \\
\hline Intercept & 1 & 2.9111 & 0.0376 & $<0.0001$ & 1.7978 & 0.0229 & $<0.0001$ \\
Ln (Area) & 1 & -0.1539 & 0.0253 & $<0.0001$ & -0.0458 & 0.0148 & 0.0020 \\
Dist & 1 & 0.0074 & 0.0252 & 0.7685 & -0.0119 & 0.0148 & 0.4199 \\
F_type2 & 1 & 0.0497 & 0.0494 & 0.3145 & 0.0523 & 0.0296 & 0.0774 \\
F_type3 & 1 & 0.0449 & 0.0713 & 0.5289 & 0.0467 & 0.0426 & 0.2736 \\
SizeCL0 & 1 & 0.0785 & 0.1193 & 0.5105 & 0.0559 & 0.0706 & 0.4283 \\
SizeCL1 & 1 & -0.0615 & 0.0529 & 0.2451 & 0.0180 & 0.0316 & 0.5686 \\
SizeCL3 & 1 & 0.7935 & 0.2224 & 0.0004 & 0.2369 & 0.1283 & 0.0649 \\
\hline
\end{tabular}

Of the 35 major bird species, significant negative associations of forest area with individual bird counts were observed in nine out of 35 bird species (Table 3). The species that were found frequently in shrubs or farming areas were: the Oriental turtle dove (Streptopelia orientalis), Eurasian tree sparrow (Passer montanus), and vinous-throated parrotbill (Sinosuthora webbiana). Meanwhile, positive associations of bird count with forest area were significant for four species: the common kestrel (Falco tinnunculus), Indian cuckoo (Cuculus micropterus), grey-backed thrush (Turdus pallidus), and yellow-throated bunting (Emberiza elegans). Analysis of the Eurasian tree sparrow showed inconsistent results for forest area between count and zero-inflation processes. 
Table 3. Test result summary for individual species abundance.

\begin{tabular}{|c|c|c|c|c|c|c|c|}
\hline Species & Scientific Name & Ln (Area) ${ }^{1}$ & Dist & SizeCL0 & SizeCL1 & SizeCL3 & Test Type ${ }^{2}$ \\
\hline \multirow[t]{2}{*}{ Common kestrel } & \multirow[t]{2}{*}{ Falco tinnunculus } & $0.661 * * 3$ & -0.840 & $2.527 * *$ & -0.230 & -4.172 & NB \\
\hline & & 1.127 & $-1.641 * *$ & 1.727 & -1.014 & 3.784 & Zero-process \\
\hline Ring-necked pheasant & Phasianus colchicus & -0.055 & -0.067 & 0.207 & -0.036 & 0.213 & NB \\
\hline Oriental turtle dove & Streptopelia orientalis & $-0.241^{* * *}$ & 0.006 & 0.048 & 0.114 & -0.463 & NB \\
\hline \multirow[t]{2}{*}{ Indian cuckoo } & \multirow[t]{2}{*}{ Cuculus micropterus } & $0.751^{* * *}$ & $-0.934^{* *}$ & 1.059 & 0.499 & -7.415 & NB \\
\hline & & $1.280^{* *}$ & $-1.337 *$ & 3.044 & 0.690 & -8.309 & Zero-process \\
\hline \multirow{3}{*}{$\begin{array}{l}\text { Broad-billed roller } \\
\text { Japanese pygmy } \\
\text { woodpecker }\end{array}$} & Eurystomus orientalis & 0.098 & $0.320 *$ & -0.747 & 0.187 & $2.613^{*}$ & NB \\
\hline & \multirow[t]{2}{*}{ Dendrocopos kizuki } & 0.231 & -0.392 & $1.239 *$ & 0.587 & $1.824 *$ & NB \\
\hline & & 0.497 & -0.430 & $1.718^{*}$ & 1.449 & 2.160 & Zero-process \\
\hline Great spotted woodpecker & Dendrocopos major & $-0.178 *$ & 0.057 & -0.200 & 0.150 & $1.587^{* *}$ & NB \\
\hline \multirow{2}{*}{ Grey-headed woodpecker } & \multirow{2}{*}{ Picus canus } & -0.381 & -0.022 & 0.484 & $-1.009 *$ & -6.694 & NB \\
\hline & & $-1.321 * *$ & -0.187 & 1.385 & -1.477 & 3.491 & Zero-process \\
\hline Grey wagtail & Motacilla cinerea & -0.183 & -0.070 & 0.051 & -0.684 & -22.127 & NB \\
\hline Olive-backed pipit & Anthus hodgsoni & -0.165 & 0.069 & 0.775 & 0.593 & -0.363 & NB \\
\hline Brown-eared bulbul & Microscelis amaurotis & -0.048 & -0.049 & $0.516^{* *}$ & -0.004 & -0.223 & NB \\
\hline Bull-headed Shrike & Lanius bucephalus & -0.029 & -0.100 & 0.184 & 0.238 & -21.743 & NB \\
\hline Daurian redstart & Phoenicurus auroreus & $-0.154^{* *}$ & -0.083 & $0.593 *$ & -0.067 & -1.030 & NB \\
\hline Scaly thrush & Zoothera dauma & -0.177 & $0.353^{* *}$ & 0.144 & 0.271 & -22.056 & NB \\
\hline Grey-backed thrush & Turdus hortulorum & 0.098 & -0.010 & -0.188 & -0.394 & -0.302 & NB \\
\hline \multirow[t]{2}{*}{ Pale thrush } & \multirow[t]{2}{*}{ Turdus pallidus } & $0.228 *$ & -0.061 & 0.735 & 0.415 & -1.389 & NB \\
\hline & & 0.844 * & -0.167 & 2.648 & $2.667 *$ & -17.408 & Zero-process \\
\hline \multirow[t]{2}{*}{ Vinous-throated parrotbill } & \multirow[t]{2}{*}{ Sinosuthora webbiana } & $-0.222 * *$ & 0.109 & $0.727 *$ & 0.077 & -0.491 & NB \\
\hline & & 0.026 & $0.158 *$ & -0.059 & -0.256 & -0.727 & Zero-process \\
\hline Yellow-browed warbler & Phylloscopus inornatus & -0.251 & -0.010 & 0.197 & 0.332 & 1.746 & NB \\
\hline Asian stubtail & Urosphena squameiceps & 0.165 & -0.017 & -0.827 & -0.452 & -21.6280 & NB \\
\hline Eastern-crowned warbler & Phylloscopus coronatus & 0.151 & $0.403^{* *}$ & -22.772 & 0.240 & $1.779 *$ & NB \\
\hline Long-tailed tit & Aegithalos caudatus & -0.028 & -0.057 & 0.035 & 0.133 & 0.016 & NB \\
\hline
\end{tabular}


Table 3. Cont.

\begin{tabular}{|c|c|c|c|c|c|c|c|}
\hline Species & Scientific Name & $\operatorname{Ln}$ (Area) ${ }^{1}$ & Dist & SizeCL0 & SizeCL1 & SizeCL3 & Test Type ${ }^{2}$ \\
\hline & & $0.261^{* *}$ & -0.046 & 0.625 & $0.324 *$ & -0.322 & Zero-process \\
\hline Marsh tit & Poecile palustris & -0.056 & -0.056 & 0.291 & -0.200 & 0.754 & NB \\
\hline Coal tit & Periparus ater & -0.150 & 0.024 & -0.623 & -0.255 & 2.1570 * & NB \\
\hline Great tit & Parus major & $-0.062 *$ & -0.031 & 0.052 & -0.030 & $0.462 *$ & NB \\
\hline \multirow{2}{*}{ Varied tit } & Sittiparus varius & -0.099 & $0.110 *$ & -0.610 & -0.194 & -0.356 & NB \\
\hline & & $-0.370 * *$ & $0.216^{*}$ & -0.704 & -0.330 & 0.464 & Zero-process \\
\hline Eurasian nuthatch & Sitta europaea & -0.044 & 0.084 & -0.300 & $-0.841^{* *}$ & -0.612 & NB \\
\hline \multirow[t]{2}{*}{ Yellow-throated bunting } & Emberiza elegans & -0.025 & $-0.194^{* *}$ & 0.138 & 0.137 & -1.037 & NB \\
\hline & & $0.158 *$ & $-0.221 *$ & -0.683 & -0.183 & -0.161 & Zero-process \\
\hline Black-faced bunting & Emberiza spodocephala & -0.236 & -0.004 & 0.508 & 0.052 & -25.395 & NB \\
\hline \multirow[t]{2}{*}{ Eurasian tree sparrow } & Passer montanus & $-0.139 *$ & -0.123 * & -0.469 & $-0.283 *$ & -1.232 & NB \\
\hline & & $0.157 *$ & -0.014 & 0.343 & 0.249 & 0.888 & Zero-process \\
\hline Black-naped oriole & Oriolus chinensis & -0.026 & 0.030 & -1.346 & -0.034 & 0.666 & NB \\
\hline White-cheeked starling & Sturnus cineraceus & -0.152 & 0.071 & 0.032 & -0.401 & -21.847 & NB \\
\hline Eurasian jay & Garrulus glandarius & 0.010 & 0.003 & 0.183 & 0.014 & -0.452 & NB \\
\hline Azure-winged magpie & Cyanopica cyanus & -0.143 & 0.050 & -0.911 & 0.115 & -1.802 & NB \\
\hline Long-billed crow & Corvus macrorhynchos & $-0.462 * *$ & 0.132 & $3.075^{* * *}$ & -0.216 & 0.729 & NB \\
\hline Common buzzard & Buteo buteo & $-0.362 * *$ & 0.047 & -1.005 & 0.192 & -8.249 & NB \\
\hline
\end{tabular}

${ }^{1}$ Notation: Ln: natural logarithm; Area: forest area; Dist: distance to forest edge; SizeCL: Tree size class 0-3 (for further details, refer to Table 1 and the main text). ${ }^{2}$ Species reported only with NB statistics were analyzed by negative binomial model. Species reported both with NB (for count data) and zero-process (for zero-count) were analyzed by zero-inflated modelling approach. ${ }^{3}$ Significance level: ${ }^{* * *} p<0.001 ; * * p<0.01 ; p^{*}<0.1$. 
Observation counts for nine species showed significant associations with distance to nearest forest edge (Table 3). Observation counts for the broad-billed roller (Eurystomus orientalis), scaly thrush (Zoothera dauma), yellow-browed warbler (Phylloscopus coronatus), varied tit (Sittiparus varius), and vinous-throated parrotbill showed a tendency to increase as distance to forest edge increased. In contrast, four of the nine species showed a negative association with distance: the common kestrel, Indian cuckoo, yellow-throated bunting, and Eurasian tree sparrow.

Forests with very small (size class 0 ) or very large classes (i.e., size class 3 ) of trees had higher bird counts. In both cases, there were more individuals observed of six species than in the size class 2 . However, size class 1 showed inconsistent results when compared with size class 2 (Table 3).

Overall, fifteen of the 35 major bird species showed statistically significant associations with either forest area or distance to forest edge. The broad-billed roller, pale thrush (T. pallidus), and eastern crowned warbler (P. coronatus) coincide with the general classification scheme for forest interior species. Frequently, those species were observed more in forests with larger areas and bigger size classes, and were also located further from the forest edge. In contrast, the Oriental turtle dove, great spotted woodpecker (Dendrocopos major), Daurian redstart (Phoenicurus auroreus), common buzzard (Buteo buteo), long-billed crow (Corvus macrorhynchos), and great tit (Parus major) can be regarded as edge species. However, several species (six species with significant results) exhibited somewhat contradictory results when analyzed in relation to forest area and distance. For example, observational frequency of the common kestrel (F. tinnunculus) was not significantly affected by distance from forest edge.

It is also notable that there were observational differences in birds within similar species groups. For example, observations of the great spotted woodpecker were significantly, and negatively, associated with larger forest area. In contrast, observation counts of the Japanese pygmy woodpecker (D. kizuki) were not affected by forest area. Only large tree size class (i.e., size class 3 ) was associated with the number of woodpeckers counted. Similar results can also be found among tits: the coal tit (Periparus alter), great tit, and varied tit (Table 3).

\section{Discussion and Conclusions}

Forest characteristics, including size, have long been known to be significant factors affecting avian communities. Moreover, the general assumption regarding the relationship between bird species diversity and forest size is that reduced forest area causes a consequential decrease in species diversity $[4,30,47-49]$. However, the results of this study were unexpected in that forests patches with larger areas tended to have lower species diversity. Presumably, this can be attributed to the fact that forest sizes across the study region had been fragmented for a long time, rendering the average forest size quite small (Table 1). In the southern forests of the United States, McIntyre [47] suggests that an approximately 10-13 ha patch of forest is the threshold size that can provide similar forest conditions to a contiguous forest. In addition, she also emphasizes that there were considerable variations in avian community responses between individual patches and forest patch sizes by individual patches. A possible interpretation of these assertions is that a core habitat that has not been affected by external conditions requires a certain amount of edge habitat as a buffer [49]. However, the average forest patch size in this study region was only approximately 5 ha. Therefore, the fragmented forest patches within the study region might not hold enough larger patch sizes to detect the effects of the core habitats.

Furthermore, due to regional reforestation about 40 years ago [40], the composition and structure of the forests in this study region might be relatively simple and homogeneous [50]. As a result, even a large-sized forest in this region might provide less diverse habitats and resources. Freemark and Merriam [4] argue that habitat heterogeneity can be more important than forest size for edge species. Therefore, it can be hypothesized that small-sized forest patches, generated by various and intense human influences, have created a more diverse array of habitats (including forest edge) and food resources [37]. Thus, this increase in habitat and resource diversity results in higher avian species diversity than in larger forest patches. As a conservation implication, the establishment of 
strategies to increase bird species diversity should not only take into account forest patch size but also habitat heterogeneity.

In this study, the positive relationship between tree size and avian diversity and abundance also reveals an optimistic view. Large trees are essential to some species, especially for cavity-nesting birds such as woodpeckers [51-53]. Therefore, avian communities within the study area would respond positively to an increase in tree size over time and continued forest management into the future. Furthermore, an increase in abandoned agricultural lands (e.g., rice paddies) due to socio-economic factors within the study region would create new ecological characters and consequences [54]. Therefore, further research and monitoring efforts on avian communities is needed.

To conserve species diversity, understanding habitat preferences for specific species plays a key role in developing forest management plans [20]. Without consideration of habitat suitability for target species, management efforts or plans for the species, such as constructing forested or green corridors, may limit their effectiveness [55]. To a certain extent, this study provides useful information for the conservation or management of several bird species by evaluating bird responses to shifts in habitat conditions.

In this study, several bird species showed notable trends of occurrence when related to forest size and distance to forest edge. If this study classified a species showing negative associations with forest size and/or distance to forest edge as a forest-edge species, then the forest-edge species were more distinctly and abundantly identified than the forest-interior species. This result coincides with the previously stated general expectation and the results of past studies $[38,56]$. The current study's findings can provide forest land managers with useful information to make decisions when accounting for the responses of those forest edge and interior bird species.

Contradictory results to the forest edge-interior species classification scheme for six bird species were also discovered in this study. The implication is that those species' occurrences were more strongly affected by the availability of other resources (e.g., food) [57], biotic interactions (e.g., predation) [58], or establishing territory [47] rather than habitat itself. For example, the vinous-throated parrotbill, which is known as an edge species, showed a conflicting result. The vinous-throated parrotbill had a higher probability of occurrence as distance to the forest edge increased. However, the vinous-throated parrotbill showed a strong preference for living in dense shrubs, which were more likely found near the forest edge area. Also, this may be an indication that the forest edge-interior species scheme is too simplistic in its implementation within the study region. For example, where an area is small and fragmented, a certain forest patch could consist of mostly large-size trees. Conversely, a juvenile forest can occupy a much larger area due to the area being recently replanted. In this case, Imbeau et al. [32] suggest that successional stages in forest growth play an important role in habitat preference for bird species. Furthermore, a long history of agriculture and urbanization in the study region has distorted the natural variation [47]. Consequently, the true effects of the tested factors might be masked by such confounding ramifications $[59,60]$.

Interestingly, according to habitat conditions, differences were found in the frequency of bird observations among similar species. The results, presumably, represent niche partitioning. For example, woodpeckers and tits showed slightly different occurrence patterns within similar species groups (Table 3). This might be explained in part by the species development of preferred habitat due to the long history of human land use, where even smaller forest patches can support a high number of bird species in the study region [61]. Furthermore, this also suggests that conservation of old-growth and large-sized forests within the region is important to maintain bird species diversity [62].

There are several potential limitations of this study that must be considered when interpreting the results. First, this study employed point count sampling instead of nest surveys. Therefore, concomitant sampling bias [31,63], imperfect detection in practice [64], and subsequent diversity underestimation must be taken into account [47]. In addition, the modeling framework used in this study (i.e., species distribution models) assumes equilibrium between birds and environmental factors $[65,66]$. Thus, the ability to interpret results regarding recently disturbed forests or migratory 
birds (in this study, the Indian cuckoo, eastern crowned warbler, and scaly thrush) might be limited [67]. Finally, improved model performance could be obtained by adding potentially influential explanatory variables, such as seasonality [47], forest structure, patch connectivity [68], shape complexity [69], and biotic interactions [70]. These variables were not examined in this study due to a lack of data availability.

Author Contributions: O.-S.C. and J.S. conceived/designed the experiment, collected data, and revised the manuscript. A.S. collected/processed data and revised the manuscript. W.J. and J.K.L. performed the data analyses and wrote the manuscript.

Funding: This research was supported by the Incheon National University.

Acknowledgments: We are grateful to Mathilde Perez-Huet and Amy Paine for revising the manuscript.

Conflicts of Interest: The authors declare no conflict of interest.

\section{References}

1. Park, C.; Xing, R.; Hanaoka, T.; Kanamori, Y.; Masui, T. Impact of energy efficient technologies on residential $\mathrm{CO}_{2}$ emissions: A comparison of Korea and China. Energy Procedia 2017, 111, 689-698. [CrossRef]

2. Henderson, V. Urbanization in developing countries. World Bank Res. Obs. 2002, 17, 89-112. [CrossRef]

3. Kim, K.H.; Pauleit, S. Landscape character, biodiversity and land use planning: The case of Kwangju City Region, South Korea. Land Use Policy 2007, 24, 264-274. [CrossRef]

4. Daily, G.C.; Polasky, S.; Goldstein, J.; Kareiva, P.M.; Mooney, H.A.; Pejchar, L.; Ricketts, T.H.; Salzman, J.; Shallenberger, R. Ecosystem services in decision making: Time to deliver. Front. Ecol. Environ. 2009, 1, 21-28. [CrossRef]

5. Freemark, K.E.; Merriam, H.G. Importance of area and habitat heterogeneity to bird assemblages in temperate forest fragments. Biol. Conserv. 1986, 36, 115-141. [CrossRef]

6. McGarigal, K.; McComb, W.C. Relationships between landscape structure and breeding birds in the Oregon Coast Range. Ecol. Monogr. 1995, 65, 235-260. [CrossRef]

7. Rands, M.R.; Adams, W.M.; Bennun, L.; Butchart, S.H.; Clements, A.; Coomes, D.; Entwistle, A.; Hodge, I.; Kapos, V.; Scharlemann, J.P.; Sutherland, W.J. Biodiversity conservation: Challenges beyond 2010. Science 2010, 329, 1298-1303. [CrossRef] [PubMed]

8. Tuff, K.T.; Tuff, T.; Davies, K.F. A framework for integrating thermal biology into fragmentation research. Ecol. Lett. 2016, 19, 361-374. [CrossRef]

9. Boulinier, T.; Nichols, J.D.; Hines, J.E.; Sauer, J.R.; Flather, C.H.; Pollock, K.H. Forest fragmentation and bird community dynamics: Inference at regional scales. Ecology 2001, 82, 1159-1169. [CrossRef]

10. Lee, D.; Kim, E.; Choi, J.; Oh, K. The effects of development on forest-patch characteristics and bird diversity in Suji, South Korea. Landsc. Ecol. Eng. 2010, 6, 171-179. [CrossRef]

11. Jung, J.K.; Kim, S.T.; Lee, S.Y.; Park, C.G.; Park, J.K.; Lee, J.H. A comparison of diversity and species composition of ground beetles (Coleoptera: Carabidae) between conifer plantations and regenerating forests in Korea. Ecol. Res. 2014, 29, 877-887. [CrossRef]

12. Fujita, A.; Maeto, K.; Kagawa, Y.; Ito, N. Effects of forest fragmentation on species richness and composition of ground beetles (Coleoptera: Carabidae and Brachinidae) in urban landscapes. Entomol. Sci. 2008, 11, $39-48$. [CrossRef]

13. Iida, S.; Nakashizuka, T. Forest fragmentation and its effect on species diversity in sub-urban coppice forests in Japan. For. Ecol. Manag. 1995, 73, 197-210. [CrossRef]

14. Zhu, H.; Xu, Z.F.; Wang, H.; Li, B.G. Tropical rain forest fragmentation and its ecological and species diversity changes in southern Yunnan. Biodivers. Conserv. 2004, 13, 1355-1372. [CrossRef]

15. Wenguang, Z.; Yuanman, H.; Jinchu, H.; Yu, C.; Jing, Z.; Miao, L. Impacts of land-use change on mammal diversity in the upper reaches of Minjiang River, China: Implications for biodiversity conservation planning. Landsc. Urban Plan. 2008, 85, 195-204. [CrossRef]

16. Mitchell, M.G.; Bennett, E.M.; Gonzalez, A. Linking landscape connectivity and ecosystem service provision: Current knowledge and research gaps. Ecosystems 2013, 16, 894-908. [CrossRef]

17. Baskent, E.Z. Controlling spatial structure of forested landscapes: A case study towards landscape management. Landsc. Ecol. 1999, 14, 83-97. [CrossRef] 
18. Ranius, T.; Jansson, N. The influence of forest regrowth, original canopy cover and tree size on saproxylic beetles associated with old oaks. Biol. Conserv. 2000, 95, 85-94. [CrossRef]

19. Caldwell, M.M.; Meister, H.P.; Tenhunen, J.D.; Lange, O.L. Canopy structure, light microclimate and leaf gas exchange of Quercus coccifera L. in a Portuguese macchia: Measurements in different canopy layers and simulations with a canopy model. Trees 1986, 1, 25-41. [CrossRef]

20. Jonsson, B.G.; Kruys, N.; Ranius, T. Ecology of species living on dead wood-lessons for dead wood management. Silva Fenni. 2005, 39, 289-309. [CrossRef]

21. Wilson, R.G. Topographic Influences on a Forest Microclimate. Master's Thesis, McGill University, Montreal, QC, Canada, May 1968.

22. Young, A.; Mitchell, N. Microclimate and vegetation edge effects in a fragmented podocarp-broadleaf forest in New Zealand. Biol. Conserv. 1994, 67, 63-72. [CrossRef]

23. Davies-Colley, R.J.; Payne, G.W.; Van Elswijk, M. Microclimate gradients across a forest edge. N. Z. J. Ecol. 2000, 24, 111-121.

24. Gibbs, J.P. Distribution of woodland amphibians along a forest fragmentation gradient. Landsc. Ecol. 1998, 13, 263-268. [CrossRef]

25. Brand, L.A.; George, T.L. Response of passerine birds to forest edge in coast redwood forest fragments. Auk 2000, 118, 678-686. [CrossRef]

26. Watson, J.E.M.; Whittaker, R.J.; Dawson, T.P. Habitat structure and proximity to forest edge affect the abundance and distribution of forest-dependent birds in tropical coastal forests of southeastern Madagascar. Biol. Conserv. 2004, 120, 311-327. [CrossRef]

27. Natuhara, Y.; Imai, C. Prediction of species richness of breeding birds by landscape-level factors of urban woods in Osaka Prefecture, Japan. Biodivers. Conserv. 1999, 8, 239-253. [CrossRef]

28. Yamaura, Y.; Ikeno, S.; Sano, M.; Okabe, K.; Ozaki, K. Bird responses to broad-leaved forest patch area in a plantation landscape across seasons. Biol. Conserv. 2009, 142, 2155-2165. [CrossRef]

29. Park, C.R.; Lee, W.S. Relationship between species composition and area in breeding birds of urban woods in Seoul, Korea. Landsc. Urban Plan. 2000, 51, 29-36. [CrossRef]

30. Whitcomb, R.F.; Lynch, J.F.; Klimkiewicz, M.K.; Robbins, C.S.; Whitcomb, B.L.; Bystrak, D. Effects of forest fragmentation on avifauna of the eastern deciduous forest. In Forest Island Dynamics in Man-Dominated Landscapes; Burgess, R.L., Sharpe, D.M., Eds.; Springer-Verlag: New York, NY, USA, 1981; pp. 125-205.

31. Villard, M.A. On forest-interior species, edge avoidance, area sensitivity, and dogmas in avian conservation. Auk 1998, 115, 801-805.

32. Imbeau, L.; Drapeau, P.; Mönkkönen, M. Are forest birds categorised as "edge species" strictly associated with edges? Ecography 2003, 26, 514-520. [CrossRef]

33. Kurosawa, R.; Askins, R.A. Effects of habitat fragmentation on birds in deciduous forests in Japan. Conserv. Biol. 2003, 17, 695-707. [CrossRef]

34. Scott, J.M.; Heglund, J.H.; Morrison, M.L.; Haufler, J.B.; Raphael, M.G.; Wall, W.A.; Samson, F.B. (Eds.) Predicting Species Occurrences: Issues of Accuracy and Scale; Island Press: Washington, DC, USA, 2002; p. 868.

35. Austin, M.P.; Meyers, J.A. Current approaches to modelling the environmental niche of eucalypts: Implication for management of forest biodiversity. For. Ecol. Manag. 1996, 85, 95-106. [CrossRef]

36. Stauffer, F.; Best, L.B. Habitat selection by birds of riparian communities: Evaluating effects of habitat alterations. J. Wildl. Manag. 1980, 44,1-15. [CrossRef]

37. Lacko, J.; Topercer, J.; Súl'ovský, M. How disturbances and management practices affect bird communities in a Carpathian river ecosystem? Acta Oecol. 2018, 88, 29-40. [CrossRef]

38. Noss, R.F. A regional landscape approach to maintain diversity. BioScience 1983, 33, 700-706. [CrossRef]

39. Angelstam, P.; Roberge, J.M.; Lõhmus, A.; Bergmanis, M.; Brazaitis, G.; Dönz-Breuss, M.; Edenius, L.; Kosinski, Z.; Kurlavicius, P.; Lārmanis, V.; et al. Habitat modelling as a tool for landscape-scale conservation: A review of parameters for focal forest birds. Ecol. Bull. 2004, 51, 427-453.

40. Korea Forest Service. Statistical Yearbook of Forestry 2018; Korea Forest Service: Daejeon, South Korea, 2018; p. 444.

41. MOLIT Statistics System. Available online: http://stat.molit.go.kr/portal/cate/engStatListPopup.do (accessed on 11 December 2018). 
42. Kim, E.S.; Choi, H.I. Estimation of the relative severity of floods in small ungauged catchments for preliminary observations on flash flood preparedness: A case study in Korea. Int. J. Environ. Res. Public Health 2012, 9, 1507-1522. [CrossRef]

43. Weather Information. Available online: http://www.weather.go.kr/weather/climate/past_table.jsp (accessed on 26 January 2019).

44. Melville, G.; Cowling, A. Line-Transect Sampling. In Encyclopedia of Environmetrics; El-Shaarawi, A.H., Piegorsch, W.W., Dean, C., Eds.; Wiley Online Library, 2013. [CrossRef]

45. Martin, T.G.; Wintle, B.A.; Rhodes, J.R.; Kuhnert, P.M.; Field, S.A.; Low-Choy, S.J.; Tyre, A.J.; Possingham, H.P. Zero tolerance ecology: Improving ecological inference by modelling the source of zero observations. Ecol. Lett. 2005, 8, 1235-1246. [CrossRef] [PubMed]

46. Zuur, A.F.; Ieno, E.N.; Walker, N.J.; Saveliev, A.A.; Smith, G.M. Zero-truncated and zero-inflated models for count data. In Mixed Effects Models and Extensions in Ecology with R; Springer: New York, NY, USA, 2009; pp. 261-293.

47. McIntyre, N.E. Effects of forest patch size on avian diversity. Landsc. Ecol. 1995, 10, 85-99. [CrossRef]

48. MacArthur, R.H.; Wilson, E.O. The Theory of Island Biogeography; Princeton University Press: Princeton, NJ, USA, 2001.

49. Fahrig, L. Effects of habitat fragmentation on biodiversity. Annu. Rev. Ecol. Evol. Syst. 2003, 34, 487-515. [CrossRef]

50. Lee, D.K.; Kang, H.S.; Park, Y.D. Natural restoration of deforested woodlots in South Korea. For. Ecol. Manag. 2004, 201, 23-32. [CrossRef]

51. Bull, E.L.; Meslow, E.C. Habitat requirements of the pileated woodpecker in northeastern Oregon. J. For. 1977, 75, 335-337.

52. Kosiński, Z.; Ksit, P.; Winiecki, A. Nest sites of Great Spotted Woodpeckers Dendrocopos major and Middle Spotted Woodpeckers Dendrocopos medius in near-natural and managed riverine forests. Acta Ornithol. 2006, 41, 21-32. [CrossRef]

53. Conner, R.N.; Hooper, R.G.; Crawford, H.S.; Mosby, H.S. Woodpecker nesting habitat in cut and uncut woodlands in Virginia. J. Wildl. Manag. 1975, 39, 144-150. [CrossRef]

54. Do, Y.; Lineman, M.; Joo, G.J. Effects of agricultural abandonment on carabid beetles in paddy fields. Balt. J. Coleopterol. 2012, 12, 65-76.

55. Chasko, G.G.; Gates, J.E. Avian habitat suitability along a transmission-line corridor in an oak-hickory forest region. Wildl. Monogr. 1982, 82, 3-41.

56. Whitaker, D.M.; Montevecchi, W.A. Breeding bird assemblages associated with riparian, interior forest, and nonriparian edge habitats in a balsam fir ecosystem. Can. J. For. Res. 1997, 27, 1159-1167. [CrossRef]

57. Santos, T.; Telleria, J. Edge effects on nest predation in Mediterranean fragmented forests. Biol. Conserv. 1992, 60, 1-5. [CrossRef]

58. Heske, E.J.; Robinson, S.K.; Brawn, J.D. Predator activity and predation on songbird nests on forest-field edges in east-central Illinois. Landsc. Ecol. 1999, 14, 345-354. [CrossRef]

59. Egger, M.; Schneider, M.; Smith, G.D. Spurious precision? Meta-analysis of observational studies. BMJ: Brit. Med. J. 1998, 316, 140. [CrossRef]

60. Ewers, R.M.; Didham, R.K. Confounding factors in the detection of species responses to habitat fragmentation. Biol. Rev. 2006, 81, 117-142. [CrossRef]

61. Chase, J.M.; Leibold, M.A. Ecological Niches: Linking Classical and Contemporary Approaches; University of Chicago Press: Chicago, IL, USA, 2003.

62. Jamoneau, A.; Chabrerie, O.; Closset-Kopp, D.; Decocq, G. Fragmentation alters beta-diversity patterns of habitat specialists within forest metacommunities. Ecography 2012, 35, 124-133. [CrossRef]

63. Bibby, C.J.; Burgess, N.D.; Hill, D.A.; Mustoe, S. Bird Census Techniques; Elsevier: Amsterdam, The Netherlands, 2000.

64. Zipkin, E.F.; Dewan, A.; Royle, J.A. Impacts of forest fragmentation on species richness: A hierarchical approach to community modelling. J. Appl. Ecol. 2009, 46, 815-822. [CrossRef]

65. Guisan, A.; Thuiller, W. Predicting species distribution: Offering more than simple habitat models. Ecol. Lett. 2005, 8, 993-1009. [CrossRef]

66. Miller, J. Species distribution modeling. Geogr. Compass 2010, 4, 490-509. [CrossRef] 
67. Václavík, T.; Meentemeyer, R.K. Equilibrium or not? Modelling potential distribution of invasive species in different stages of invasion. Divers. Distrib. 2012, 18, 73-83. [CrossRef]

68. Uezu, A.; Metzger, J.P.; Vielliard, J.M. Effects of structural and functional connectivity and patch size on the abundance of seven Atlantic forest bird species. Biol. Conserv. 2005, 123, 507-519. [CrossRef]

69. Helzer, C.J.; Jelinski, D.E. The relative importance of patch area and perimeter-area ratio to grassland breeding birds. Ecol. Appl. 1999, 9, 1448-1458.

70. Giannini, T.C.; Chapman, D.S.; Saraiva, A.M.; Alves-dos-Santos, I.; Biesmeijer, J.C. Improving species distribution models using biotic interactions: A case study of parasites, pollinators and plants. Ecography 2013, 36, 649-656. [CrossRef]

(C) 2019 by the authors. Licensee MDPI, Basel, Switzerland. This article is an open access article distributed under the terms and conditions of the Creative Commons Attribution (CC BY) license (http://creativecommons.org/licenses/by/4.0/). 